\title{
KEDUDUKAN ANAK NON MUSLIM TERHADAP HARTA WARISAN PEWARIS ISLAM DITINJAU DARI KITAB UNDANG-UNDANG HUKUM PERDATA (KUHPerdata)
}

\begin{abstract}
Ahmad Royani, SH, MH
Abstrak

Perkawinan, merupakan pertalian yang sah antara seorang lelaki dan seorang perempuan untuk waktu yang lama. Undang-undang memandang perkawinan hanya dari hubungan keperdataan, demikian Pasal 26 Burgerlijk Wetboek. Perkawinan merupakan suatu peristiwa penting dalam kehidupan manusia, karena perkawinan tidak saja menyangkut pribadi kedua calon suami istri, tetapi juga menyangkut urusan keluarga dan masyarakat. Pada umumnya perkawinan dianggap sebagai sesuatu yang suci dan karenanya setiap agama selalu menghubungkan kaedah-kaedah perkawinan dengan kedah-kaedah agama. Pemberlakuan Undang-Undang Nomor 12 Tahun 2006 Tentang Kewarganegaraan RI, dipandang sebagai kemajuan positif sebab mengakomodasikan tuntutan jaman, terkait dengan mobilitas dan aktivitas "antar manusia antar negara". Undang-undang tersebut merupakan solusi yang dianggap terbaik untuk memecahkan permasalahan yang rentan dan sensitif yaitu kewarganegaraan seseorang terkait dengan status kedudukan hukum anak hasil perkawinan campuran antara Warga Negara Indonesia (WNI) dengan Warga Negara Asing (WNA). Di dalam Undang-Undang tersebut, menerapkan azas-azas kewarganegaraan universal, yaitu asas Ius Sanguinis, Ius Soli dan Campuran. Artinya, Si anak dapat memilih kewarganegaraan sendiri sesuai dengan apa yang terbaik bagi dirinya. Anak hasil perkawinan campuran hendaknya memanfaatkan ketentuan tersebut untuk melegalisasikan kewarganegaraan sesudah 18 tahun. Aparat yang menangani status kewarganegaraan anak hasil perkawinan campuran agar melaksanakan ketentuan Undang-Undang kewarganegaraan secara adil dan tidak diskriminatif.
\end{abstract}

\section{Kata Kunci : Perkawinan}

\section{PENDAHULUAN}

Perkawinan di Indonesia diatur dalam Undang-Undang Nomor 1 Tahun 1974 tentang Perkawinan. Pengertian Perkawinan menurut Pasal 1 ialah :

"Ikatan lahir batin antara seorang pria dengan seorang wanita sebagai suami istri dengan tujuan membentuk keluarga (rumah tangga) yang bahagia dan kekal berdasarkan Ketuhanan Yang Maha Esa”.

Perkawinan, merupakan pertalian yang sah antara seorang lelaki dan seorang perempuan untuk waktu yang lama. Undang-undang memandang perkawinan hanya dari hubungan keperdataan, demikian Pasal 26 Burgerlijk Wetboek ${ }^{68}$ Perkawinan merupakan suatu peristiwa

${ }^{68}$ Subekti, Pokok-Pokok Hukum Perdata, (cetakan ke-31), Jakarta : Intermasa, 2003, h. 23. penting dalam kehidupan manusia, karena perkawinan tidak saja menyangkut pribadi kedua calon suami istri, tetapi juga menyangkut urusan keluarga dan masyarakat. Pada umumnya perkawinan dianggap sebagai sesuatu yang suci dan karenanya setiap agama selalu menghubungkan kaedah-kaedah perkawinan dengan kedah-kaedah agama. Manusia dalam menempuh pergaulan hidup dalam masyarakat, ternyata tidak dapat terlepas dari adanya saling ketergantungan antara manusia dengan yang lainnya. Hal itu dikarenakan, sesuai dengan kedudukan manusia sebagai mahluk sosial, yang suka berkelompok atau berteman dengan manusia lainnya. Hidup bersama merupakan salah satu sarana untuk memenuhi kebutuhan hidup manusia, baik kebutuhan yang bersifat jasmani maupun yang bersifat rohani. Demikian pula bagi seorang laki-laki ataupun seorang perempuan yang telah mencapai usia tertentu, maka ia tidak akan 
lepas dari permasalahan tersebut. Ia ingin memenuhi kebutuhan hidupnya, dengan melaluinya bersama dengan orang lain yang bisa dijadikan curahan hati penyejuk jiwa, tempat berbagi suka dan duka. Hidup bersama antara seorang laki-laki dan perempuan sebagai pasangan suami istri dan telah memenuhi ketentuan hukumnya, ini yang lazimnya disebut sebagai sebuah perkawinan. Perkawinan (pernikahan) pada hakekatnya, adalah merupakan ikatan lahir dan batin antara seorang laki-laki dan perempuan untuk membentuk suatu keluarga yang kekal dan bahagia. Perkawinan campuran telah, merambah seluruh pelosok Tanah Air dan kelas masyarakat. Globalisasi informasi, ekonomi, pendidikan, dan transportasi telah menggugurkan stigma bahwa kawin campur adalah perkawinan antara ekspatriat kaya dan orang Indonesia. ${ }^{69}$

2. Penulis juga menganalisis sejumlah potensi masalah yang bisa timbul dari pengaturan harta warisan terhadap anak non muslim. Seiring berkembangnya zaman dan sistem hukum, UndangUndang kewarisan terhadap anak non muslim yang baru ini penerapannya semoga dapat terus dikritisi oleh para ahli hukum perdata internasional, terutama untuk mengantisipasi potensi masalah. Sehingga dalam penulisan judul ini saya memilih " KEDUDUKAN ANAK NON MUSLIM TERHADAP HARTA WARISAN PEWARIS ISLAM DITINJAU KITAB UNDANGUNDANG HUKUM PERDATA (KUHPerdata)".

\section{A. Perumusan Masalah}

Berdasarkan latar belakang
masalah tersebut diatas penulis
mengetengahkan dua permasalahan
yaitu:

1. Bagaimana pengaturan anak non muslim terhadap harta warisan pewaris islam ditinjau dari KUHPerdata ?

69

http://norickyujustice.blogspot.com/2011/04/statushukum-anak-dari-hasil-perkawinan.html
2. Bagaimana Kedudukan Anak Non Muslim Dari Pewaris Islam Menurut KUHPerdata ?

\section{B. Tujuan Penelitian}

Dalam penelitian ini ada dua tujuan yang ingin diketahui antara :

1. Untuk mengetahui pengaturan anak non muslim terhadap harta warisan pewaris islam ditinjau dari KUHPerdata.

2. Untuk mengetahui Akibat Hukum Bagi Penerima Waris Anak Non Muslim Dari Pewaris Islam Menurut KUHPerdata .

\section{Manfaat Penelitian}

Di dalam penelitian sangat diharapkan adanya manfaat dan kegunaan karena nilai suatu penelitian ditentukan oleh besarnya manfaat yang dapat diambil dari penelitian tersebut. Adapun manfaat yang diharapkan penulis dari penelitian ini antara lain :

1. Manfaat Teoritis

a. Hasil penelitian ini diharapkan dapat memberikan sumbangan pemikiran bagi pengembangan ilmu hukum khususnya mengenai pengaturan anak non muslim terhadap harta pewaris.

b. Hasil penelitian ini dapat di pakai sebagai acuan bagi penelitian penelitian selanjutnya yang sejenis.

c. Diharapkan dengan adanya penelitian ini dapat ditemukan metode yang efektif guna mencegah bahkan mengatasi maraknya Perkawinan non muslim (beda agama) yang tidak sesuai dengan undang-undang yang berlaku di kemudian hari.

\section{Manfaat Praktis}

a. Hasil penelitian ini dapat meningkatkan dan mengembangkan daya pikir dan analisis penulis tentang masalahmasalah hukum, sekaligus untuk mengukur sejauh mana kemampuan penulis dalam menerapkan ilmu yang diperoleh selama kuliah di Fakultas Hukum Universitas Islam Lamongan. 
b. Diharapkan dapat membantu dan member masukan serta tambahan pengetahuan bagi pihak yang terkait dengan masalah yang diteliti khususnya tentang pengaturan anak non muslim terhadap harta pewaris.

c. Dapat memberikan sumbangan pemikiran bagi penegak hukum agar dipakai sebagai bahan pertimbangan dan dasar pengambilan keputusan ataupun kebijakannya dalam menangani pengaturan anak non muslim terhadap harta pewaris.

d. Hasil penelitian ini diharapkan mampu menjawab permaslahan yang timbul diranah hukum tentang pengaturan anak non muslim terhadap harta pewaris.

\section{Metode Penelitian}

\section{Tipe Penelitian}

Tipe Penelitian hukum yang di lakukan adalah penelitian Yuridis normatife (hukum normatif). Metode Penelitian Hukum normatif adalah suatu prosedur penelitian ilmiah untuk menemukan kebenaran berdasarkan logika keilmuan hukum dari sisi

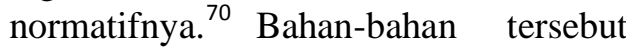
disusun secara sistematis, dikaji kemudian dicari suatu kesimpulan dalam hubungannya dengan masalah yang diteliti.

\section{HASIL DAN PEMBAHSAN}

Secara umum dikatakan anak adalah seorang yang dilahirkan dari perkawinan antara seorang perempuan dengan seorang laki-laki dengan tidak menyangkut bahwa seseorang yang dilahirkan oleh wanita meskipun tidak pernah melakukan pernikahan tetap dikatakan anak. Anak juga merupakan cikal bakal lahirnya suatu generasi baru yang merupakan penerus cita-cita perjuangan bangsa dan sumber daya manusia bagi pembangunan Nasional.Anak adalah asset

${ }^{70}$ Jhonny ibrahim, Teori \& Metode Penelitian Hukum Normatif, Banyumedia Publishing, Malang 2006.h .57.
bangsa.Masa depan bangsa dan Negara dimasa yang akan datang berada ditangan anak sekarang.Semakin baik keperibadian anak sekarang maka semakin baik pula kehidupan masa depan bangsa.Begitu pula sebaliknya, Apabila keperibadian anak tersebut buruk maka akan hancur pula kehidupan bangsa yang akan datang. Pada umumnya orang berpendapat bahwa masa kanak-kanak merupakan masa yang panjang dalam rentang kehidupan. $^{7}$

Bagi kehidupan anak, masa kanak-kanak seringkali dianggap tidak ada akhirnya, sehingga mereka tidak sabar menunggu saat yang didambakan yaitu pengakuan dari masyarakat bahwa mreka bukan lagi anak-ank tapi orang dewasa. Menurut Hurlock (1980), manusia berkembang melalui beberapa tahapan yang berlangsung secara berurutan, terus menerus dan dalam tempo perkembangan y6ang tertentu, terus menerus dan dalam tempo perkembangan yang tertentu dan bias berlaku umum. Untuk lebih jelasnya tahapan perkembangan tersebut dapat dilihat pada uraian tersebut: - Masa pra-lahir : Dimulahi sejak terjadinya konsepsi lahir - Masa jabang bayi : satu hari-dua minggu. Masa Bayi : dua minggu-satu tahun. Masa anak : - masa anak-anak awal : 1 tahun-6 bulan, Anak-anak lahir : 6 tahun-12/13 tahun. - Masa remaja : 12/13 tahun-21 tahun - Masa dewasa : 21 tahun-40 tahun. - Masa tengah baya : 40 tahun-60 tahun. - Masa tua : 60 tahun-meninggal . ${ }^{72}$

Dalam pemaknaan yang umum mendapat perhatian tidak saja dalam bidang ilmu pengetahuan (the body of knowledge) tetapi dapat di telah dari sisi pandang sentralistis kehidupan.Misalnya agama, hukum dan sosiologi menjadikan pengertian anak semakin rasional dan aktual dalam lingkungan social. Untuk meletakan anak kedalam pengertian subjek hukum maka diperlukan unsur-

\footnotetext{
https://andibooks.wordpress.com/definisi-anak/

${ }^{72}$ Ibid
} 
unsur internal maupun eksternal di dalam ruang lingkup untuk menggolongkan status anak tersebut.Unsure-unsur tersebut adalah sebagai berikut: - Unsur internal pada diri anak. Subjek Hukum: sebagai manusia anak juga digolongkan sebagai human right yang terkait dalam ketentuan peraturan perundang-undangan. Ketentuan dimaksud diletakkan pada anak dalam golongan orang yang belum dewasa, seseorang yang berada dalam perwalian, orang yang tidak mampu melakukan perbuatan huku. Persamaan hak dan kewajiban anak : anak juga mempunyai hak dan kewajiban yang sama dengan dengan orang dewasa yang diberikan oleh ketentuan perturan perundang-undangan dalam melakyukan perbuatan hukum. Hukum akan meletakan anak dalam posisi seabagai perantara hukum untuk dapat disejajarkan dengan kedudukan orang dewasa atau untuk disebut sebagai subjek hukum Unsur eksternal pada diri anak. - Ketentuan hukum atau persamaan kedudukan dalam hukum (equality before the low) dapat memberikan legalitas formal terhadap anak sebagai seorang yang tidak mampu untuk berbuat peristiwa hukum yang ditentukan oleh ketentuan peraturan-peraturan hukum itu sendiri, atau meletakan ketentuan hukum yang memuat perincian tentang klasifikasi kemampuan dan kewenangan berbuat peristiwa hukum dari anak yang bersangkutan. - Hak-hak privilegeyang diberikan Negara atau pemerintah yang timbul dari UUD dan peraturan perundang-undangan . Untuk dapat memahami pengertian tentang anak itu sendiri sehingga mendekati makna yang benar, diperlukan suatu pengelompokan yang dapat dilihat dari berbagai aspek kehidupan, yaitu aspek agam, ekonomi, sosiologis dan hukum.

Pengertian Anak Menurut Hukum Perdata. Pengertian anak menurut hukum perdata dibangun dari beberapa aspek keperdataan yang ada pada anak sebagai seseorang subjek hukum yang tidak mampu. Aspekaspek tersebut adalah: - Status belum dewasa (batas usia) sebagai subjek hukum. - Hak-hak anak di dalam hukum perdata. Pasal 330 KUHPerdata me3mberikan pengertian anak adalah orang yang belum dewasa dan seseorang yang belum mencapai usia batas legitimasi hukum sebagai subjek hukum atau layaknya subjek hukum nasional yang ditentukan oleh perundang-undangan perdata. Dalam ketentuan hukum perdata anak mempunyai kedudukan sangat luas dan mempunyai peranan yang amat penting, terutama dalam hal memberikan perlindungan terhadap hak-hak keperdataan anak, misalnya dalam masalah dala masalah pembagian harta warisan, sehingga anak yang berada dalam kandungan seseorang dianggap telah dilahirkan bilamana kepentingan si anak menghendaki sebagaimana yang dimaksud oleh pasal 2 KUHPerdata. ${ }^{74}$

\section{Pengertian Anak Menurut}

Hukum Pidana. Pengertian anak menurut hukum pidana lebih diutamakan pada pemahaman terahadap hak-hak anak yang harus dilindungi, karena secara kodrat memiliki subtansi yang lemah dan di dalam system hukum dipandang sebagai subjek hukum yang dicangkokan dari bentuk pertanggungjawaban sebagaimana layaknya seseorang sebjek hukum yang normal. Pengertian anak dalam aspek hukum pidana menimbulkan aspek hukum positif terhadap proses normalisasi anak dari perilaku menyimpang untuk membentuk kepribadian dan tanggung jawab yang pada akhirnya menjadikan anak tersebut berhak atas kesejahteraan yang layak dan masa depan yang baik.

Pada hakekatnya, kedudukan status pengertian anak dalam hukum pidana meliputi dimensi-dimensi pengertian sebagai berikut: - Ketidak mampuan untuk pertanggung jawaban 
tindak pidana. - Pengembalian hak-hak anak dengan jalan mensubtitusikan hak-hak anak yang timbul dari lapangan hukum keperdataan, tatnegara dengan maksud untuk mensejahterakan anak. - Rehabilitasi, yaitu anak berhak untuk mendapat proses perbaikan mental spiritual akibat dari tindakan hukum pidana yang dilakukan anak itu sendiri. - Hakhak untuk menerima pelayanan dan asuhan. - Hak anak-anak dalam proses hukum acara pidana. Jika ditilik pada pasal 45 KUHP maka anak didefinisikan sebagai anak yang belum dewasa apabila belum berumur 16 tahun.Oleh sebab itu jika anak tersebut tersangkut dalam perkara pidana hakim boleh memerintahkan supaya si tersalah itu dikembalikan kepada orang tuanya, walinya atau pemeliharaanya dengan tidak dikenakan suatu hukuman, atau memerintahkan supaya diserahkan kepada pemerintah dengan tidak dikenakan sesuatu hukuman. Dengan demikian di dalam ketentuan hukum pidana telah memberikan perlindungan terahadap anak-anak yang kehilangan kemerdekaan, karena anak dipandang sebagai subjek hukum yang berada pada usia yang belum dewasa sehingga harus tetap dilindungi segala kepentingan dan perlu mendapatkan hak-hak yang khusus yang diberikan oleh negara atau pemerintah. Jadi dari berbagi defenisi tentang anak di atas sebenarnya dapatlah diambil suatu benang merah yang menggambarkan apa atau siapa sebenarnya yang dimaksud dengan anak dan berbagai konsekwensi yang diperolehnya sebagi penyandang gelar anak tersebut.

Ahli waris menurut undangundang ini digolongkan menjadi beberapa golongan.dengan pengertian apabila golongan pertama tidak ada maka golongan kedua yang berhak menerima sedangkan golongan yang lainnya tidak berhak dan begitu seterusnya.Pada masalah ini prof. subekti membagi tiga golongan ahli waris diantaranya adalah:

\section{Ahli waris golongan ke-1}

a) Anak-anak baik yang sah maupun tidak sah,beserta keturunannya dan seterusnya dalam garis lurus ke bawah.

b) Suami atau istei yang hidup terlama

\section{Ahli waris golongan ke-2}

a) Orang tua (ayah dan ibu)

b) Saudara-saudara(sekandung atau sebapak atau seibu saja,saudara sebapak atau seibu bersama dengan saudara sekandung,mempunyai cara pembagian tersendiri.

\section{Ahli waris golongan ke-3}

a) Keluarga sedarah dalam garis lurus ke atas,baik dari pihak ibu maupun dari pihak ayah. yaitu kakek dan nenek dari pihak ayah dan ibu.

b) Harta warisan di bagi dua (kloving) terlebih dahulu, separoh di berikan kepada pancar ayah dan separoh di berikan kepada pancar ibu.

Menurut Islam perkawinan antar agama dapat dilakukan oleh laki-laki muslim saja sepanjang wanita non muslim yang akan dinikahinya tersebut ialah berasal dari golongan ahli kitab, sedangkan bagi wanita muslim hal tersebut tidak dimungkinkan. Sedangkan kedudukan/status anak yang terdapat di dalam hukum perkawinan pada umumnya menurut konsepsi hukum Perdata Barat merupakan anak yang dihasilkan dari suatu perkawinan yang bersifat keperdataan belaka tanpa adanya unsur-unsur lain, seperti misalnya unsur religiusitas (Pasal 26 BW). Dari perbedaan di atas rupanya juga terdapat persamaan mengenai staus anak yang terdapat di dalam hukum perkawinan pada umumnya menurut kedua konsepsi tersebut, yaitu bahwa keduanya samasama mengakui bahwa anak yang sah ditentukan atas dua hal sebagai berikut: ${ }^{75}$ 1. anak tersebut dilahirkan dari suatu perkawinan yang sah.

\section{${ }^{75}$ Ibid}


Kedudukan Anak Hasil Perkawinan Antar Agama Dalam Hal Pembagian Harta Warisan Anak menurut hukum kewarisan Perdata Barat merupakan ahli waris menurut undangundang atau $a b$ intestato (Pasal 832 KUHPerdata). Anak-anak disini dimasukkan ke dalam golongan pertama dari orang-orang yang berhak menjadi ahli waris bersama-sama dengan turunturunan dari anak-anak tersebut. Kemudian hak mewaris seorang anak menurut hukum Islam dibagi atas dua, yaitu kewarisan Islam menurut bilateral Hazairin maupun menurut Ahlul Sunnah Wal Jama'ah (Patrilineal). Sedangkan, hak mewaris anak tersebut yang tercantum di dalam kompilasi hukum Islam merupakan penggabungan antara sistem kewarisan Ahlul Sunnah Wal Jamma'ah (Patrilineal) dan sistem kewarisan bilateral Hazairin. Menurut Undang-Undang Perkawinan anak dalam hal ini tidak dapat mewaris, karena undang-undang tersebut telah menutupi suatu kemungkinan terjadinya perkawinan antar agama dengan adanya Pasal 2 ayat 1 yang menyatakan "perkawinan adalah sah, apabila dilakukan menurut hukum masingmasing agamanya dan kepercayaannya itu". Dari bunyi pasal tersebut membawa akibat bahwa anak disini hanyalah mempunyai kedudukan hukum dengan ibunya dan keluarga ibunya (Pasal 34 Undang-Undang Perkawinan), jika perkawinan antar agama tersebut tidak dapat dilangsungkan maka berakibat pada anak tersebut, yang statusnya menjadi anak luar kawin. Berbeda halnya dengan kewarisan menurut hukum Perdata Barat ini ada dalam hal tertentu yang dianggap tidak patut dalam menjadi seorang ahli waris sesuai dengan Pasal 839 KUHPerdata, yang dianggap tidak patut menjadi ahli waris dan karenanya dikecualikan dari pewarisan adalah: ${ }^{76}$

a) Mereka yang telah dihukum karena dipersalahkan membunuh atau mencoba membunuh si yang meninggal. b) Mereka yang dengan keputusan hakim pernah dipersalahkan karena secara fitnah telah mengajukan pengaduan terhadap si pewaris, ialah suatu pengaduan telah melakukan suatu kejahatan yang terancam dengan hukuman penjara 5 (lima) tahun lamanya atau hukuman yang lebih berat.

c) Mereka yang dengan kekerasan atau perbuatan telah mencegah si yang meninggal untuk membuat dan mencabut surat wasiatnya.

d) Mereka yang telah menggelapkan, merusak atau memalsukan surat wasiat si yang meninggal.

Ketidak patutan ini menghalangi ahli waris tersebut untuk menerima warisan, hal ini diadakan dengan pemikiran dari pembuat undang-undang untuk melindungi si pewaris dan keluarganya dari tindakan yang tidak beritikad baik dari pihak lain (ahli waris) yang menginginkan harta warisan dari pewaris dengan cara yang tidak baik. Ahli warisnya adalah keturunan garis lurus baik yang sah maupun luar kawinyang dibagi dalam golongan ahli waris. Pewarisan yang dibahas dalam pengaturan tidak mewaris pada Pasal 839 KUHPerdata tidak mengatur tentang pembagian waris yang disebabkan oleh perkawinan antar mereka yang berbeda agama. Oleh karenanya perbedaan agama tidak menjadi permasalahan menurut pengaturan KUHPerdata mereka para prinsipnya tetap berhak untuk saling mewaris, karena tidak terdapat larangan untuk mewaris bagi mereka. Oleh karenanya kedudukan anak dari mereka yang melangsungkan perkawinan yang berbeda agama relatif lebih terlindungi dengan ketentuan hukum Perdata Barat ini.

\section{KESIMPULAN}

Berdasarkan pemaparan yang telah disampaikan maka penelitian ini memberikan pokok-pokok kesimpulan sebagai berikut :

1. Dalam Kitab undang-undang Hukum Perdata pembagian 
golongan yang dapat menerima warisan dibagi menjadi 4 golongan, yakni : Dalam golongan pertama, dimasukan anak - anak berserta turunan turunan dalam garis lancang kebawah. Golongan kedua dimasukan orang tua dan saudara - saudara dari si meninggal. Golongan ketiga sebagai ahli waris, jika tidak terdapat sama sekali anggota keluarga dari golongangan pertama dan kedua, harta peninggalan itu dipecah menjadi dua bagian yang sama. Satu bagian untuk para anggota keluarga pihak ayah dan yang lainnya untuk keluarga pihak ibu. Golongan keempat, ahli waris dari harta yang ditinggalkan, apabila golongan pertama, kedua dan ketiga tidak ada. Maka warisan jatuh pada ahli waris yang terdekat pada tiap garis. Apabila seluruh ahli waris dari golongan pertama sampai ke empat tidak ada, maka seluruh harta warisan jatuh pada negara.

2. Kedudukan Anak Hasil Perkawinan Antar Agama Dalam Hal Pembagian Harta Warisan Anak menurut hukum kewarisan Perdata Barat merupakan ahli waris menurut undang-undang atau $a b$ intestato (Pasal 832 KUHPerdata). Anak-anak disini dimasukkan ke dalam golongan pertama dari orang-orang yang berhak menjadi ahli waris bersama-sama dengan turunturunan dari anak-anak tersebut. Kemudian hak mewaris seorang anak menurut hukum Islam dibagi atas dua, yaitu kewarisan Islam menurut bilateral Hazairin maupun menurut Ahlul Sunnah Wal Jama'ah (Patrilineal). Menurut Undang-Undang Perkawinan anak dalam hal ini tidak dapat mewaris, karena undang-undang tersebut telah menutupi suatu kemungkinan terjadinya perkawinan antar agama. Dari bunyi pasal 2 ayat 1 undang-undang perkawinan tersebut, membawa akibat bahwa anak disini hanyalah mempunyai kedudukan hukum dengan ibunya dan keluarga ibunya (Pasal 34 Undang-Undang Perkawinan), jika perkawinan antar agama tersebut tidak dapat dilangsungkan maka berakibat pada anak tersebut, yang statusnya menjadi anak luar kawin.

\section{DAFTAR PUSTAKA}

Jhony ibrahim, Teori \& Metode Penelitian Hukum Normatif, Banyumedia Publishing, Malang, Tahun 2006.

Peter Mahmud Marzuki, Penelitian Hukum, Kencana Prenadia Group, Jakarta, Tahun 2010

Subeki, Pokok-pokok hokum perdata / Subekti-cet.31-Jakarta Intermasa, 2003

Surini Ahlan Sjarif, SH,. MH. Dan DR. Nurul Elmiyah, SH,. MH. Hukum Kewarisan Perdata Barat : Pewarisan Menurut UndangUndang Kencana 2010

Subekti, Ringkasan tentang Hukum Keluarga dan Hukum Waris/Subekti -Cet. 1- Jakarta : Intermasa, 1990

PERATURAN

UNDANGAN :

PERUNDANG-

Undang-undang Dasar Negara Republik Indonesia Tahun 1945

Kitab Undang-undang Hukum Perdata (KUHPerdata)

Undang-undang Nomor 1 Tahun 1974 Tentang Perkawinan

INTERNET :

http://wahyurishandi.blogspot.com/2012/12/ judul-skripsi-kedudukan-anak-non$\underline{\text { muslim.html }}$ 
http://www.islamnyamuslim.com/2012/12/h ukum-pernikahan-beda-agamaislam-dan.html

http://mohammadsyafiie.blogspot.co $\underline{\mathrm{m} / 2013 / 02 / \text { hak-non-muslim- }}$ terhadap-harta-waris.html https://andibooks.wordpress.com/definisianak/

http://anugrahjayautama.blogspot.com/2012/ 06/hukum-waris-menurut-bw.html http://kangzems.blogspot.com/2013/11/hukum-warismenurut-kitab-undang-undang.html http://dingklikkelas.blogspot.com/2014/03/h ukum-perdata-hukum-waris.html http://www.academia.edu/3890924/hukum_ waris_berdasarkan_BW

http://gajud.blogspot.com/2012/02/pengertia n-ahli-waris-dan-harta-warisan.html

http://www.hukumonline.com/klinik/detail/lt 4ecc7cf50640b/empat-golongan-ahli-warismenurut-kuh-perdata 